\title{
Knowledge of Basic Accounting Issues of SBA Students and their View on the Qualification Level of Professional Accountants
}

\author{
Markéta Šeligová ${ }^{*}$ Ivana Koštuř́ková*
}

\begin{abstract}
:
The aim of the article is to evaluate the level of basic knowledge of accounting issues of students of the School of Business Administration in Karviná (SBA) in the Czech Republic and verify the existence of dependence of their knowledge on gender, secondary education, aspects of their university studies, and last but not least, on their work experience. Furthermore, the research aims to find out how these students perceive the importance of the qualification level of professional accountants. In order to achieve the objective of the article, a questionnaire survey was used. On the basis of the acquired nominal data, the non-parametric Kruskal-Wallis test was used to answer the first research question concerning the impact of aspects of the university study on the level of student accounting knowledge. As part of the research, 1,035 students were contacted and 709 respondents have completed the questionnaire. The perceptions of the accountant profession were examined using the Pearson's chi-square test and the Pearson's coefficient of contingency. It can be concluded from the results that the form of study and the degree of study have no influence on the level of students' knowledge. In the field of study, on the other hand, the dependence of accounting knowledge of students on this aspect has already been proved. The work experience of students was most markedly reflected in the students' accounting knowledge.
\end{abstract}

Key words: Accountant profession; Accounting, education; Kruskal-Wallis test; Pearson Chi-square test; Pearson coefficient; University studies; Work experience.

JEL classification: A10; I21; M41.

\footnotetext{
Markéta Šeligová, Silesian University in Opava, School of Business Administration in Karviná, Department of Finance and Accounting, Univerzitní náměstí 1934/3, 73340 Karviná, Czech Republic, <seligova@opf.slu.cz>, ORCID ID: 0000-0001-5034-0044.

Ivana Koštuříková, Silesian University in Opava, School of Business Administration in Karviná, Department of Finance and Accounting, Univerzitní náměstí 1934/3, 73340 Karviná, Czech Republic, <kosturikova@opf.slu.cz>, ORCID ID: 0000-0001-9258-4821.
} 
Šeligová, M. - Koštuř́íková, I.: Knowledge of Basic Accounting Issues of SBA Students and their View on the Qualification Level of Professional Accountants.

\section{Introduction}

The importance of education is constantly growing today. The educational level of the population has an increasing impact on the prosperity and economic growth of individual states. Educated and qualified individuals are the bearers of the economic and cultural development of society. Education, including lifelong learning, is closely linked to the competitiveness of companies and regions. In this context, vocational training has a crucial role to play as a system for acquiring skills and competences that respond to the rapidly changing needs of the labour market, the modernisation and innovation of manufacturing sectors and the development of the structure of employment opportunities.

The driving force of the ever-changing business environment is, among others, gradual globalisation, technical progress, innovation, but also changing social values, diversification of human resources or the use of the natural environment. These changes are reflected in the accounting, and thus subsequently affect the financial reporting. Today, there is an increasing emphasis on boosting the transparency of financial reporting, and at the same time there is a growing interest in non-financial information. This is the reason for the gradual evaluation of the accounting profession, which is not only responsible for bookkeeping, but also for providing comprehensive information, including tax or financial information.

Nowadays, emphasis is also often placed on teaching in the field of accounting in a way that reflects practice. The emphasis is not only on mentoring theoretical knowledge, but also on practical requirements. Many universities thus offer both academic study programs and professional study fields. These professional fields of study should have focused on the importance of accounting in business practice. Students are not yet sufficiently guided to the end user use of accounting, respectively, to use the information and they do not fully understand the comprehensive system of accounting policies and procedures that lead to a true and fair view. This misconception of students about their complete knowledge of accounting, its mastery in economic practice, or misconception of a suitable professional profile of a graduate for the profession of accountant can be described as a myth.

There are studies that have addressed a similar topic. For example, Watty (2005) in his study provided an insight into the quality of accounting teaching through a questionnaire survey. Academic accountants see quality as it is currently defined and promoted in their immediate work environment, as opposed to their view of how quality should be defined and promoted. As a result, quality assurance and improvement systems can currently be designed to ensure the quality 
that is supported in accounting education, rather than the quality that should be promoted.

In his study, Gurney (2009) examined the determinants of academic performance in undergraduate accounting modules for students outside of accounting. Among the determinants he included, for example, age, gender, quality of teaching, structure of the exam, etc. It was found that these factors have an influence on determining the performance of students.

Tan and Laswad (2015) examined the impact of learning styles on academic performance using the main assessment methods (exams and assignments, multiplechoice questions, etc. in the introductory accounting course). Students, who exhibit an "assimilative" learning style, have been found to perform better in some assessments than students with "different" or "supportive" learning styles; they will not be preoccupied with specific learning styles, which would improve their validity and fairness.

In their study, Cernuşca and Balaciu (2015) presented students' perceptions of the image of the accountant and the accounting profession, thus contributing to a better understanding of the possibilities for accounting and motivations for choosing this profession. The research aimed to understand the role of the accounting profession as a social identity and as a social phenomenon and consequences for academia and professional subjects.

In this context, the question arises as to whether university graduates are prepared to perform professional accountants and whether there is a correlation between students' knowledge and the requirements of Czech employers for the professional competence of professional accountants.

For this reason, the aim of the article is to evaluate the level of basic knowledge of accounting issues of students of the Faculty of Business and Entrepreneurship in Karviná (SBA) and verify the existence of their knowledge dependence on gender, secondary education, aspects of university study and last but not least on their work experience. Furthermore, to find out how these students perceive the importance of the qualification level of professional accountants. The research is thus focused on the above goals from the students' point of view.

In order to verify the dependence of students' accounting knowledge on selected aspects, the following research questions were set:

- Does the gender of students influence their basic knowledge of accounting issues?

- Does the type of secondary education attained affect their basic knowledge of accounting issues? 
Šeligová, M. - Koštuř́íková, I.: Knowledge of Basic Accounting Issues of SBA Students and their View on the Qualification Level of Professional Accountants.

- How do the form, degree and field of study affect their basic knowledge of accounting issues?

- Does the students' work experience affect their basic knowledge of accounting issues?

To analyse the perception of the importance of the qualification level of professional accountants, one research question was defined.

- Is the level of qualification of professional accountants reflected in their remuneration?

\section{Literature Review}

Education plays a key role in shaping the current and future economic growth, as annual labour costs increase significantly with higher levels of education. This development is also influenced by the quality of education; however, this impact is manifested only with a certain delay.

Brožová (2003) highlights education as prevention against unemployment in the context of greater adaptability to the changing market requirements. Riddell and Song (2011) then examined the causal effects of education on employment and unemployment, with a special focus on the extent to which education improves the re-employment of unemployed workers. The essence of vocational education is the creation and maintenance of harmony between subjective and objective qualifications. A subjective qualification is a set of competencies acquired during life with the potential possibility of use for the performance of a certain activity. Objective qualifications are demands for the performance of a specific profession (Mužík, 1998).

According to Tokarčíková, Kucharčíková and Ďurišová (2015), universities which are important centres of knowledge have a significant role in education. Students should acquire professional knowledge and should be able to apply this knowledge in solving global problems.

Boccanfuso, Larouche and Trandafir (2015), for example, examine the issue of the importance of the level of universities and the impact of quality vocational education on the employment of skilled workers. The importance of the extent of the accountant's knowledge can be defined in connection with the characteristics of the accounting profession, which is listed in the database of the National System of Occupations of the Czech Republic. The database of the National System of Occupations under the label "professional accountant" lists the following job positions: auditor, chief accountant in the business sphere, payroll accountant, professional accountant, fixed asset officer, inventory worker, accounting and audit 
specialist, independent accountant business sphere and accounting methodologies in the business sphere (MLSA, 2017).

According to Suddaby, Gendron and Lama (2009), professional accountants are defined as guardians of the public interest. Their qualities should be professional expertise, experience, independence, honesty and objectivity. The importance of professional accountants is the subject of research and expert studies by international organisations such as IFAC (2018) or ACCA (2012). The issue of the importance of professional accounting and the growing requirements for their expertise has been discussed more in the Czech Republic since 2014, when the institute of liability of members of statutory bodies was strengthened. According to the Commercial Corporations Act, the statutory body is responsible for ensuring proper bookkeeping in accordance with the concept of due diligence.

According to Šípková (2013), the accounting profession can play a crucial role in stabilising the business environment. The credibility of the accounting profession depends on how the public perceives the value that financial professionals will bring. Accounting information is important for managerial decision-making. The higher the share of the accounting profession in decision-making about strategy, search for business opportunities or risk management of the entity, the greater its importance (Jaworska, 2016).

In the database of the National System of Occupations, in terms of the accounting profession, the following positions are listed- auditor, chief accountant in the business sphere, payroll accountant, professional accountant, employee for records of fixed assets, worker for inventory records, business sphere and accounting methodologies in the business sphere (National System of Occupations, 2017).

While the positions Professional Accountant and Accountant share a similar professional profile, requiring comprehensive knowledge of accounting, the position of Accountant also requires working with accounting information and preparing financial statements in accordance with the principles of not only accounting, but also tax code and income tax law. For these positions, it is not enough to acquire knowledge at the level of memorisation and understanding and their application in practice, but it is necessary to develop the ability to assess the situation in the financial statements. Both positions require the ability to solve problems in the sense that the accountant can identify the essence of more complex problems, structure the problem, solve it systematically and prevent them in the future, can combine analytical and creative thinking.

The position of Independent Accountant requires the ability to solve problems more than in previous job positions, in the sense of identifying the causes and consequences of the problem, the use of analytical and creative thinking, 
Šeligová, M. - Koštuř́íková, I.: Knowledge of Basic Accounting Issues of SBA Students and their View on the Qualification Level of Professional Accountants.

cooperation in creating standards that prevent problems. It is evident that in addition to basic knowledge and skills of accounting for accounting cases, the ability to solve problems and use analytical and creative thinking is required, even in positions that can be performed with a complete secondary education and a high school diploma.

These requirements are also in line with the research of Jirásková (2012), who used the analysis of advertisements to determine the requirements for the professional competence of accountants in the Czech Republic. According to the analysis of the current state of teaching accounting at secondary schools, the preparation of new accountants correlates with the requirements for expertise, especially in the areas of accounting cases in financial accounting related to tax, inventory of assets and liabilities in theory, and work with accounting documents. Students are equipped with a theoretical framework in the field of compiling financial statements and internal accounting. A broader scope in the preparation of new accountants is missing.

From the above, it is clear that there are no similar studies on the issue. Many authors dealt with a similar topic, but from the perspective of employers. It is in this direction that the uniqueness of research can be seen, which focuses on the side of employees (i.e. students so far) and not on the side of employers. In this direction, a so-called grey spot was found and thus a space was created for finding out the above facts from the students' point of view. The results of the research can be provided to employers when selecting a suitable candidate for a number of accounting professions, where the employer can see how the future employees and candidates for the position perceive the accounting profession and what factors may affect accounting issues in general.

\section{Data and Methodology}

Within the internal project "New trends and specifics of accounting in the context of legislative changes in the Czech Republic", the basic knowledge of accounting issues of full-time and part-time students at OPF and their view on the importance of qualification level of professional accountants were examined in the form of a questionnaire survey. The survey was attended by 252 full-time students and 457 part-time students. The majority of students (521) were from the bachelor's degree, 188 students attended the follow-up master's degree. 178 respondents studied Accounting and Taxes, another 531 respondents studied other economic fields. The nonparametric Kruskal-Wallis test was used to answer the research questions.

According to Gravetter and Wallnau (2007), the Kruskal-Wallis test is a generalisation of the nonparametric Mann-Whitney test for more than two groups being compared. The main idea of the Kruskal-Wallis test is that under 
the null hypothesis, the combined values from all samples are so well mixed that the average orders corresponding to the individual sets are similar. To calculate the test, we again sort all the observations by size (as if they came from one selection) and assign the individual values to the order. The test statistic of the Kruskal-Wallis test has a form:

$$
Q=\frac{12}{n(n+1)} \sum_{i=1}^{k} \frac{T_{i}^{2}}{n_{i}}-3(n+1)
$$

We reject the null hypothesis at the significance level $\alpha$ when the implementation of the test statistic $\mathrm{Q}$ is greater than the critical value (quantile) corresponding to the significance level $\alpha$.

Based on the obtained nominal data, the investigated dependence was further verified using Chi-Square tests. Empirically determined frequencies (nij) were compared with theoretical frequencies or expected (eij), which represent the combined frequencies expected assuming the independence of the variables. The magnitude of the differences between the observed and expected frequencies is assessed using the following test statistics.

$$
\chi^{2}=\sum_{\mathrm{i}=1}^{\mathrm{r}} \sum_{\mathrm{j}=1}^{\mathrm{c}} \frac{\left(\mathrm{n}_{\mathrm{ij}}-\mathrm{e}_{\mathrm{ij}}\right)^{2}}{\mathrm{e}_{\mathrm{ij}}}
$$

To verify the dependence using the Pearson's chi-square test, the statistical program SPSS was used, with the help of which the level of statistical significance or significance (so-called p-value) was calculated. The achieved level of statistical significance was examined at the level of significance $\alpha=0.05$. If the $p$-value is less than 0.05 , the influence of aspects of university study on the perception of the importance of the accounting profession is demonstrated. In such a case, i.e. proving the influence between the variables, the intensity (tightness) of the dependence was further investigated using the Pearson contingency coefficient.

$$
C=\sqrt{\frac{\chi^{2}}{n+\chi^{2}}}
$$

The closer the coefficient is to 1 , the tighter the relationship between the characters. The closer the coefficient is to 0 , the weaker the dependence.

In connection with the above information, hypotheses were established within the $5 \%$ testing of statistical significance:

$\mathrm{H}_{0}$ : The selected aspect of OPF students does not affect the level of their knowledge of accounting 
Šeligová, M. - Koštuř́íková, I.: Knowledge of Basic Accounting Issues of SBA Students and their View on the Qualification Level of Professional Accountants.

$\mathrm{H}_{0}$ : The selected aspect of OPF students does not affect the perception of the manifestation of the qualification level in the remuneration of professional accountants

Selected aspects were:

- gender,

- completed secondary education,

- form of university study,

- university degree,

- field of university studies,

- students' work experience.

The knowledge of accounting issues of OPF students was tested using a questionnaire survey, where respondents were asked questions in the field of financial accounting. Subsequent evaluation was carried out using the standard classification used at universities, where a high percentage of correct answers meant a grade of A, or grade B, on the other hand, a low percentage of correct answers meant grade $\mathrm{F}$. The rating is shown in detail in the following table.

\section{Tab. 1: Method of knowledge assessment}

\begin{tabular}{|c|c|c|c|}
\hline \multicolumn{3}{|c|}{ Degree of evaluation } & \multirow{2}{*}{$\begin{array}{l}\text { Percentage of correct } \\
\text { answers }\end{array}$} \\
\hline Grade & Verbal expression & Description & \\
\hline $\mathrm{A}$ & Excellent & $\begin{array}{l}\text { outstanding performance } \\
\text { with only minor errors }\end{array}$ & $93-100 \%$ \\
\hline $\mathrm{B}$ & Very good & $\begin{array}{l}\text { above the average standard } \\
\text { but with some errors }\end{array}$ & $85-92 \%$ \\
\hline $\mathrm{C}$ & Good & $\begin{array}{l}\text { generally sound work with } \\
\text { a number of notable errors }\end{array}$ & $77-84 \%$ \\
\hline $\mathrm{D}$ & Satisfactory & $\begin{array}{l}\text { fair but with significant } \\
\text { shortcomings }\end{array}$ & $69-76 \%$ \\
\hline $\mathrm{E}$ & Sufficient & $\begin{array}{l}\text { performance meets the } \\
\text { minimum criteria }\end{array}$ & $60-68 \%$ \\
\hline $\mathrm{F}$ & Fail & $\begin{array}{l}\text { considerable further work } \\
\text { is required }\end{array}$ & $0-59 \%$ \\
\hline
\end{tabular}

Source: own processing 


\section{Results and Discussion}

In the form of a questionnaire survey, the level of knowledge in the field of accounting is achieved by full-time and part-time students at the Faculty of Business Administration. It was also found out what is their view on the level of qualification of professional accountants. As part of the research, 1,035 students were contacted, and 709 people completed the questionnaire.

\subsection{Evaluation of knowledge of accounting issues of OPF students}

The evaluation of OPF students' knowledge in the field of accounting was based on the standard classification at European universities-ECTS. For a clearer graphic representation, the students' knowledge was marked as very good in the case of evaluation with marks A and B, as good in the case of evaluation with marks $\mathrm{C}$ and $\mathrm{D}$, as sufficient in the case of evaluation with grade $\mathrm{E}$ and insufficient in the case of grade F (Fig. 1). Almost a third of the students (225) achieved a very good knowledge and 303 students demonstrated a good knowledge of accounting. Only 68 students had insufficient knowledge of accounting issues.

\section{Fig. 1 Level of accounting knowledge of OPF students}

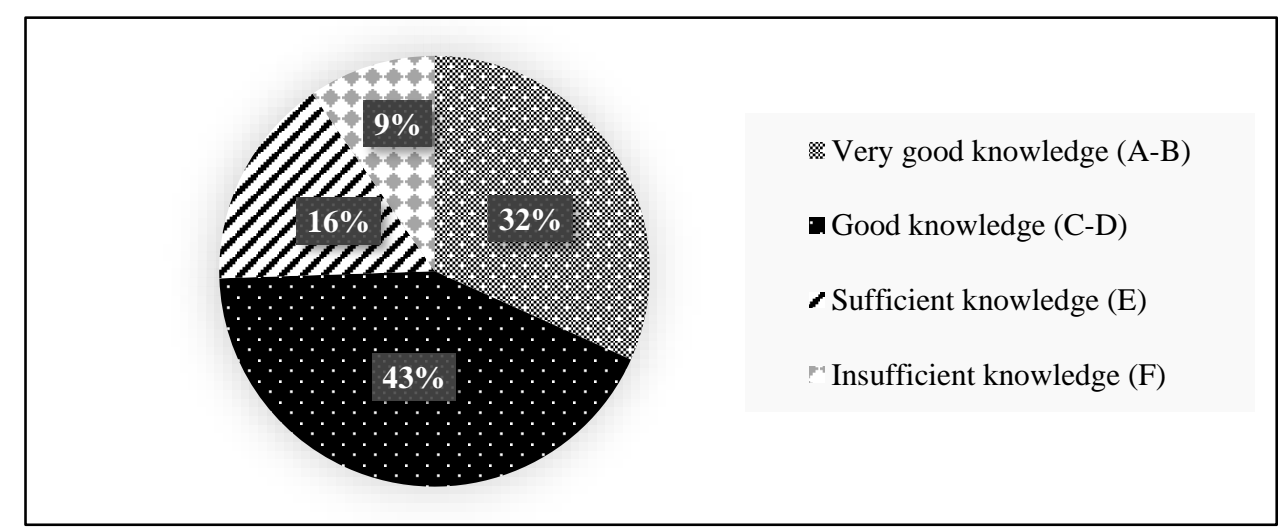

Source: authorial computation.

In the questionnaire survey took part 169 men and 540 women. As can be seen from the following Figure 2, more than a third of the students showed a very good knowledge of accounting issues. Only $23 \%$ of students achieved the same level of knowledge. In contrast, there were more than 10 percentage points more students with good knowledge than students. 
Šeligová, M. - Koštuř́íková, I.: Knowledge of Basic Accounting Issues of SBA Students and their View on the Qualification Level of Professional Accountants.

\section{Fig. 2 Level of accounting knowledge by gender}

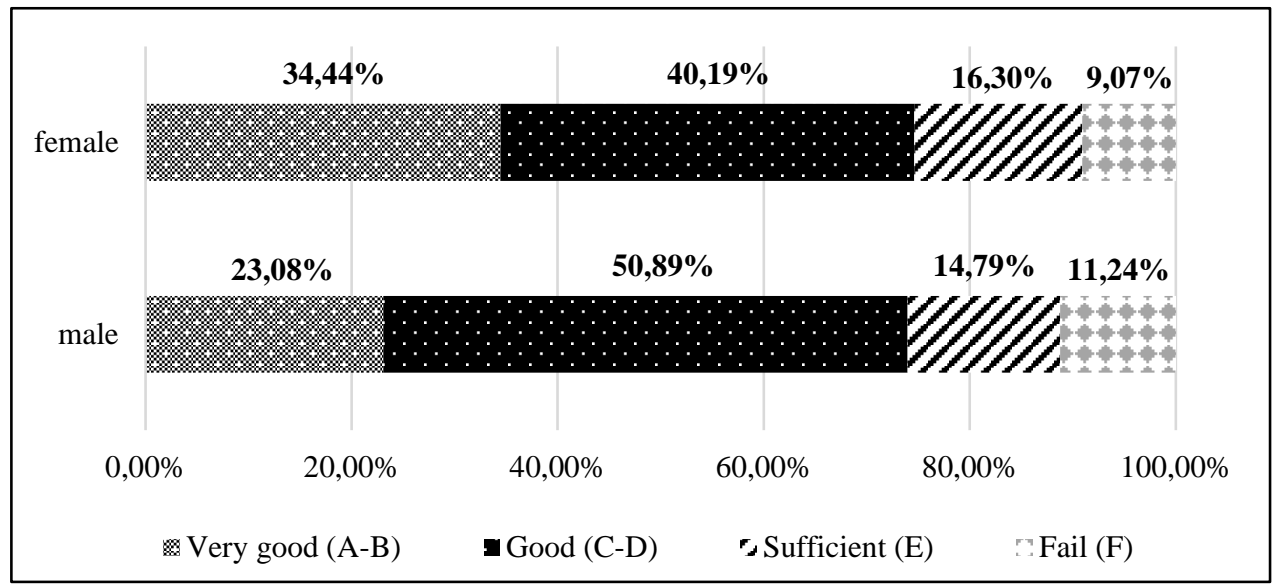

Source: authorial computation.

Very good knowledge of the basic issues of accounting was demonstrated by approximately the same number of students who achieved both general secondary education and vocational secondary education (economic and noneconomic). Significant differences are evident in the evaluation with C-D marks, when this evaluation was obtained by only $36.9 \%$ of students with general secondary education. In contrast, there were more than $40 \%$ of students with vocational education with this evaluation, as shown in Figure 3.

\section{Fig. 3 Level of accounting knowledge according to completed secondary education}

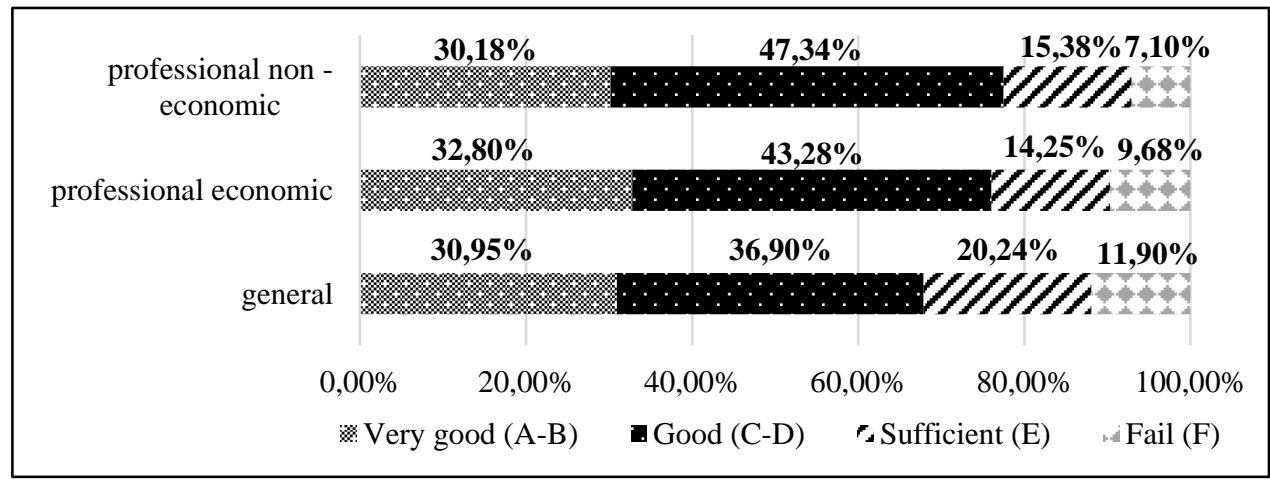

Source: authorial computation.

In the combined form of study, more students had a very good knowledge than in the full-time form. On the other hand, full-time students had rather only a good knowledge. In both forms of study, the lack of knowledge in the field of accounting 
manifested itself in approximately the same percentage of students, as shown in the following Figure 4.

Fig. 4 Level of accounting knowledge according to the form, degree and field of study

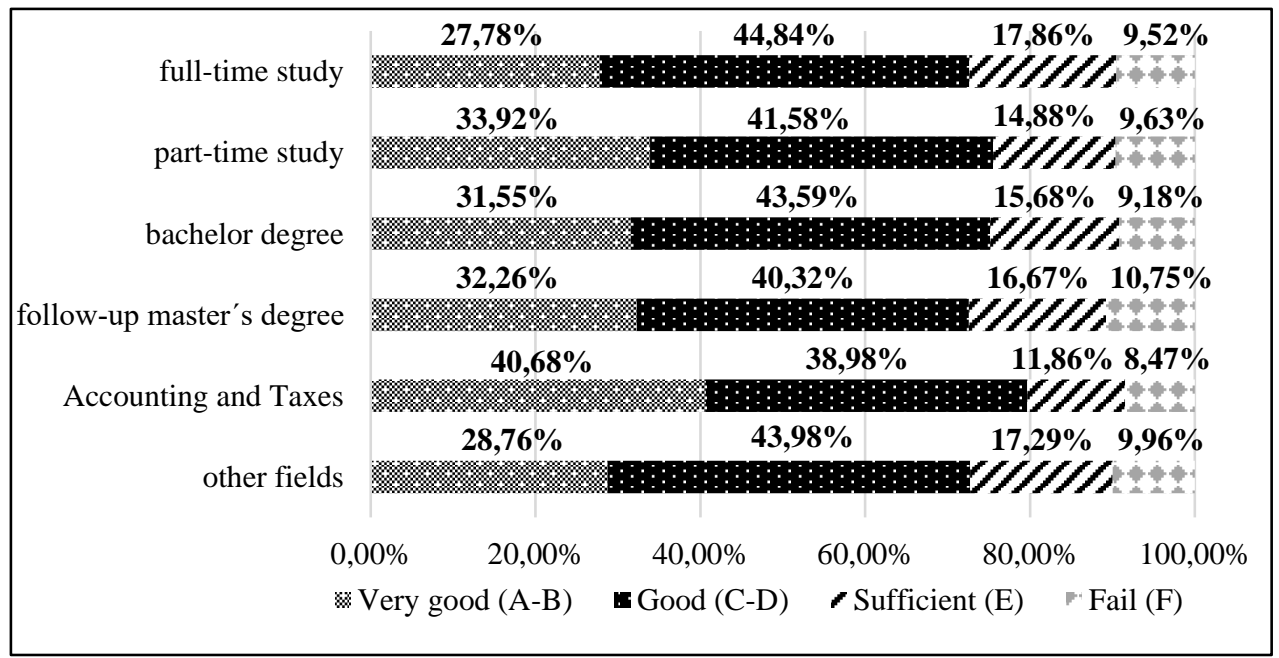

Source: authorial computation.

If we compare students of different degrees of study, namely the bachelor's degree and the subsequent master's degree, their knowledge in the field of accounting is very similar. Students of Accounting and Taxes (UD) should have the greatest awareness of accounting issues in comparison with students of other fields, as evidenced by the graph above. It is clear from it that the largest percentage of students in the field of UD demonstrated very good knowledge regarding accounting issues. The least students in this field also had insufficient accounting knowledge.

Figure 5 shows that students who have work experience in the field of economics have the most knowledge of accounting issues (42.42\%). In the case of students without work experience, this level of knowledge was achieved by only $24 \%$ of respondents. Students who have work experience but in the non-economic field have the most knowledge (45.7\%). On the other hand, in this group there is the highest percentage of students with insufficient knowledge of accounting (11.34\%). 
Šeligová, M. - Koštuř́íková, I.: Knowledge of Basic Accounting Issues of SBA Students and their View on the Qualification Level of Professional Accountants.

\section{Fig. 5 Level of accounting knowledge according to work experience}

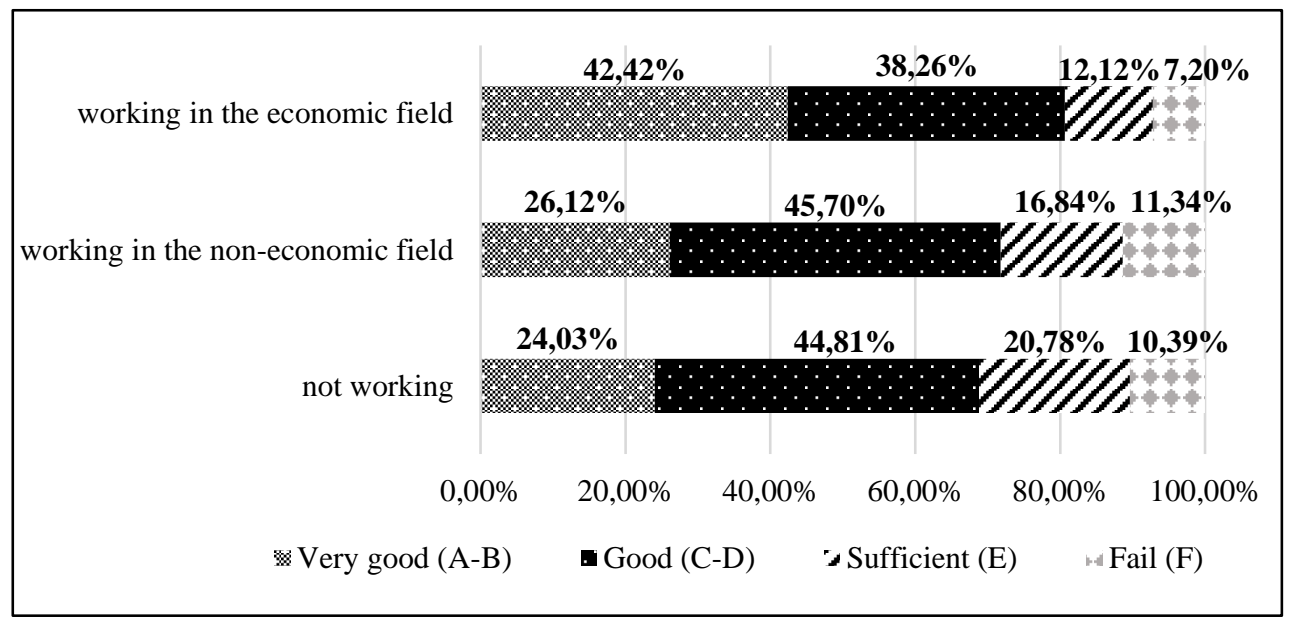

Source: authorial computation.

\subsection{The view of OPF students on the level of qualification of professional accountants}

As already mentioned, the students' view of the level of qualification of professional accountants was also examined. According to the results, the vast majority of students believe that the level of qualification of professional accountants plays an important role, with more than half of students favouring that the level of qualification should be required by the market and almost $40 \%$ are of the opinion that the qualification of professional accountants should be stipulated by law (Fig. $6)$.

\section{Fig. 6 The level of qualification of professional accountants and the importance of its role}

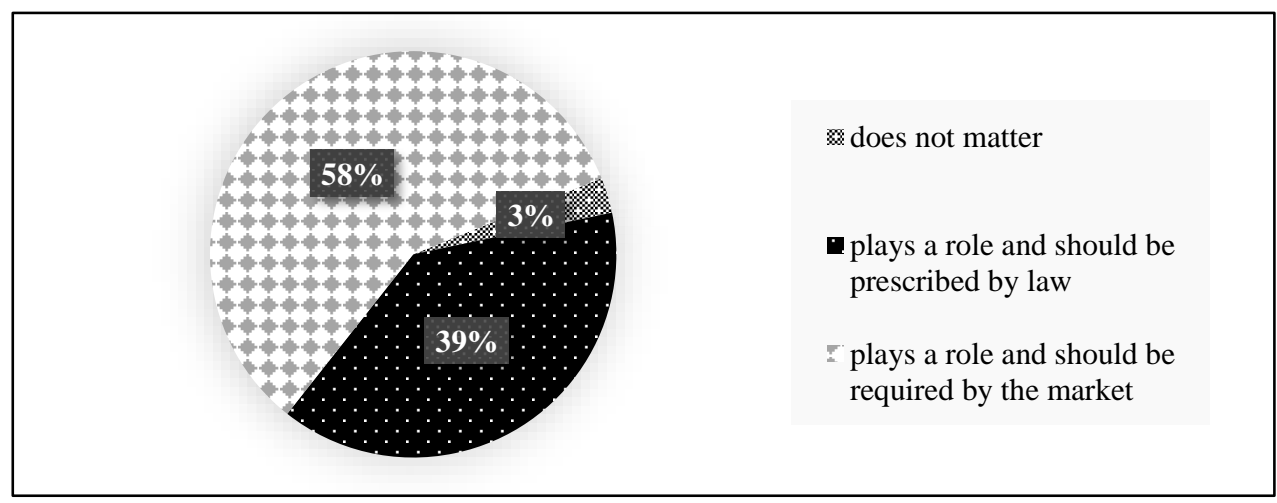

Source: authorial computation. 
The view of students on whether the level of qualification of professional accountants is reflected in their remuneration is ambiguous (Fig. 7). Only 28\% of respondents believe that the qualification level has an impact on the remuneration of professional accountants. More than a third of students (36\%) are then convinced of the opposite and the same number of respondents cannot answer the question.

Fig. 7 The level of qualification of professional accountants and its influence on remuneration

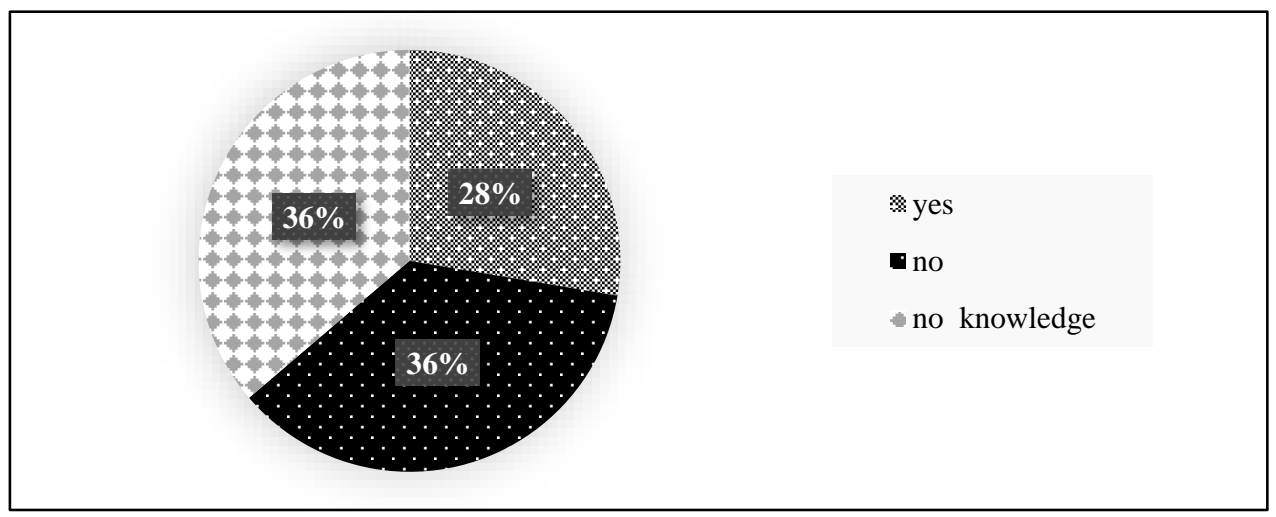

Source: authorial computation.

\subsection{The influence of selected aspects of students on their level of knowledge of accounting issues}

The non-parametric Kruskall Wallis test was used to determine the influence of gender, secondary education, aspects of university study and, last but not least, the work experience of OPF students on the level of their accounting knowledge, the results of which are shown in the following table.

Tab. 1 The influence of selected aspects of OPF students on the level of their accounting knowledge

\begin{tabular}{llccr}
\hline \multicolumn{1}{c}{ Aspects } & Test Statistics & Value & df & Asymp. Sig. \\
\hline Gender & Kruskal-Wallis H & 3.857 & 1 & $\mathbf{0 . 0 5 0}$ \\
High school education & Kruskal-Wallis H & 1.911 & 2 & 0.385 \\
Form of university study & Kruskal-Wallis H & 2.135 & 1 & 0.144 \\
University degree & Kruskal-Wallis H & 0.109 & 1 & 0.741 \\
University study field & Kruskal-Wallis H & 8.564 & 1 & $\mathbf{0 . 0 0 3}$ \\
Students' work experience & Kruskal-Wallis H & 21.567 & 2 & $\mathbf{2 . 0 7 4 E - 0 5}$ \\
N of Valid Cases & & 709 & & \\
\hline Source: auth & & & &
\end{tabular}

Source: authorial computation in the SPSS program. 
Šeligová, M. - Koštuř́íková, I.: Knowledge of Basic Accounting Issues of SBA Students and their View on the Qualification Level of Professional Accountants.

As can be seen from the results of the table, the secondary education attained, the form of study (full-time versus combined) and the degree of study (bachelor's versus post-graduate), which can affect students' level of knowledge, can mean more than 0.05. On the other hand, the dependence of students' accounting erudition on this aspect has already manifested itself in field and the field of university studies. The students 'work experience had the most significant effect on their students' knowledge of accounting.

Pearson's chi-square test was demonstrated to verify the probability of gender accounting, university studies and students' work experience (Table 2). Based on statistical significance, where the significance of significance is less than 0.05 , with $95 \%$ probability it is likely to state that the level of knowledge of OPF students depends on the gender of students, their field of study and their work experience.

Tab. 2 Dependence of selected aspects of OPF students on the level of their knowledge of accounting

\begin{tabular}{lcccr}
\hline \multicolumn{2}{c}{ Chi-Square Tests } & Value & df & Asymp. Sig. \\
\hline Gender & Pearson Chi-Square & $9.505^{\mathrm{a}}$ & 3 & 0.023 \\
University study field & Pearson Chi-Square & $10.214^{\mathrm{a}}$ & 3 & 0.017 \\
Students' work experience & Pearson Chi-Square & $24.711^{\mathrm{a}}$ & 6 & $3.862 \mathrm{E}-04$ \\
N of Valid Cases & & 709 & & \\
\hline
\end{tabular}

Source: authorial computation in the SPSS program.

To determine the intensity of the dependence, contingency coefficients were calculated and since their value is close to 0 , it is not possible to infer a close dependence (Table 3).

Tab. 3 The intensity of the dependence of selected aspects on the level of accounting knowledge

\begin{tabular}{lccr}
\hline & Symmetric Measures & Value & Appr. Sig. \\
\hline Gender & Contingency Coefficient & 0.115 & 0.023 \\
University study field & Contingency Coefficient & 0.119 & 0.017 \\
Students' work experience & Contingency Coefficient & 0.184 & $3.862 \mathrm{E}-04$ \\
N of Valid Cases & & 709 & \\
\hline
\end{tabular}

Source: authorial computation in the SPSS program. 


\subsection{Dependence of the perception of the qualification level of professional accountants on selected aspects}

Within the internal project "New trends and specifics of accounting in the context of legislative changes in the Czech Republic", the perception of the importance of the qualification level of professional accountants by OPF students in Karviná was also examined. Due to the low frequency of one answer when examining the significance of the role of the qualification level of professional accountants, it was not possible to perform the Pearson's chi-square test. Thus, only the dependence of selected aspects on the perception of the manifestation of the level of qualification on the remuneration of professional accountants was examined (Table 4).

Tab. 4 Dependence of selected aspects on the perception of the manifestation of the qualification level on the remuneration of professional accountants

\begin{tabular}{lcccr}
\hline \multicolumn{1}{c}{ Chi-Square Tests } & Value & df & Asymp. Sig. \\
\hline Gender & Pearson Chi-Square & $3.811^{\mathrm{a}}$ & 2 & 0.149 \\
High school education & Pearson Chi-Square & $8.834^{\mathrm{a}}$ & 4 & 0.065 \\
Form of university study & Pearson Chi-Square & $13.615^{\mathrm{a}}$ & 2 & $\mathbf{0 . 0 0 1}$ \\
University degree & Pearson Chi-Square & $5.477^{\mathrm{a}}$ & 2 & 0.065 \\
University study field & Pearson Chi-Square & $12.451^{\mathrm{a}}$ & 2 & $\mathbf{0 . 0 0 2}$ \\
Students' work experience & Pearson Chi-Square & $23.608^{\mathrm{a}}$ & 4 & $\mathbf{9 . 5 7 2 E - 0 5}$ \\
N of Valid Cases & & 709 & & \\
\hline
\end{tabular}

Source: authorial computation in the SPSS program.

Based on the above results, it can be stated that the perception of the expression of the level of qualification of professional accountants on their remuneration does not depend on gender, achieved secondary education and the level of university studies of the respondents. On the other hand, dependence has already manifested itself in the form and field of university studies. The most obvious is the influence of students' work experience on the perception of the expression of the qualification level on the remuneration of professional accountants.

In order to determine the intensity of the dependence between the nominal variables, the contingency coefficients were calculated using the SPSS program, which is shown in the following Table 5. Since the values of all coefficients are close to 0 , it is not possible to infer a close dependence. 
Šeligová, M. - Koštuř́íková, I.: Knowledge of Basic Accounting Issues of SBA Students and their View on the Qualification Level of Professional Accountants.

Tab. 5 The intensity of the dependence of selected aspects on the perception of the manifestation of the qualification level on the remuneration of professional accountants

\begin{tabular}{lccr}
\hline & Symmetric Measures & Value & Appr. Sig. \\
\hline Form of university study & Contingency Coefficient & 0.137 & 0.001 \\
University field & Contingency Coefficient & 0.131 & 0.002 \\
Students' work experience & Contingency Coefficient & 0.180 & $9.572 \mathrm{E}-05$ \\
N of Valid Cases & & 709 & \\
\hline
\end{tabular}

Source: authorial computation in the SPSS program.

In line with Watty (2005) study, it should be borne in mind that academic accountants see quality as it is currently defined and promoted in their immediate work environment, as opposed to their view of how quality should be defined and promoted. As a result, quality assurance and improvement systems can currently be designed to ensure the quality that is supported in accounting education, rather than the quality that should be promoted. The obtained results thus provide a valuable input to the discussion on the design of quality assurance and improvement systems in higher education in general and in the field of accounting education and the subsequent perception of the accounting profession in particular.

In the absence of any previous empirical research that would seek to identify the perception of the accounting profession, the results fill the gap in the literature by clearly identifying views on the quality of accounting education and the perception of the accounting profession.

In line with the Cernuşca and Balaciu study (2015), the accounting profession must be aligned with the current conditions the accounting system is going through in order to harmonise IFRS and European regulations and the development of information technology and the transition to the digital age. The role of the accountant is changing from a simple digital operator to a modern one. It will be part of the management team, providing strategic and financial advice and effective solutions for the proper functioning of the organisation, a modern stereotype involving creativity in accounting activities.

\section{Conclusion}

Education develops the personality of a person who will thus be equipped with knowledge, skills and competences not only for personal life, but also for the performance of a profession or work activity. The process of economic globalisation and the Czech Republic's membership in the European Union require 
further new knowledge and competencies from the accounting profession, but at the same time it opened the way for professional accountants to pursue a career at the international level and the opportunity to do business on a much larger scale. The professional qualification of an accountant is a necessary condition for the quality performance of any of a number of possible accounting specialisations at all levels.

The aim of the article was to assess the level of accounting knowledge of full-time and part-time students at OPF and to find out how these students perceive the importance of the qualification level of professional accountants. The results of the questionnaire survey show that almost $32 \%$ of the students have very good knowledge of accounting and almost $43 \%$ of the respondents have demonstrated good knowledge in this area. Using the Kruskal-Wallis test, the dependence of this knowledge on selected aspects was investigated. Dependence on three aspects was proved, namely the gender of students, the field of study, where students of Accounting and Taxes demonstrated better accounting knowledge than students of other economics at the Faculty of Business Administration in Karviná, and most of all their work experience.

These facts were confirmed using the Pearson's Chi-square test, which was also used to examine the dependence of the perception of the qualification level of professional accountants and their remuneration on selected aspects. Also in this case, the dependence on three aspects manifested itself, namely on the form and field of university study and again especially on the work experience of students.

Due to the fact that there are no similar studies on the problem, it is not possible to perform a comparison. Many authors dealt with a similar topic, but from the perspective of employers. It is in this direction that the uniqueness of research can be seen, which focuses on the side of employees (i.e. students so far) and not on the side of employers. In this direction, a so-called grey spot was found and thus a space was created for finding out the above facts from the students' point of view.

The results of the research can be provided to employers when selecting a suitable candidate for a number of accounting professions, where the employer may see how the future employees and candidates for the position perceive the accounting profession and what factors may affect accounting issues in general.

There is potential for further research in this area. Very interesting findings would certainly be brought by research focused on the employer's side, what the employer requires and what is absolutely essential for him in selecting a suitable candidate for individual job positions of an accounting nature). 
Šeligová, M. - Koštuř́íková, I.: Knowledge of Basic Accounting Issues of SBA Students and their View on the Qualification Level of Professional Accountants.

\section{Acknowledgment}

„This paper was supported by the Ministry of Education, Youth and Sports Czech Republic within the Institutional Support for Long-term Development of a Research Organization in 2020 “.

\section{References}

The Association of Chartered Certified Accountants (ACCA), 2012. 100 drivers of change for the global accountancy profession. London: ACCA. Available from: <imanet.org/insights-and-trends/the-future-of-management-accounting/100-riversof-change-for-the-global-accountancy-profession?ssopc=1>. [11 July 2019].

Boccanfuso, D., Larouche, A., Trandafir, M., 2015. Quality of Higher Education and the Labor Market in Developing Countries: Evidence from an Education Reform in Senegal. World Development, 74(2015), 412-424.

Brožová, D., 2003. Společenské souvslosti trhu práce. Praha: Sociologické nakladatelství. ISBN 80-86429-16-4.

Cernuşca, L., Balaciu, D., 2015. The Perception of the Accounting Students on the Image of the Accountant and the Accounting Profession. Journal of Economics and Business Research. 21(1). 7 - 24. ISSN 2069-9476.

Gravetter, F. J., Wallnau, L. B., 2007. Statistics for the behavioral sciences. 7th ed. Belmont, CA, US: Thomson Wadsworth. ISBN 978-0495095200.

Guney, Y., 2009. Exogenous and Endogenous Factors Influencing Students' Performance in Undergraduate Accounting Modules. Accounting Education. 18(1). 51-73.

International Federation of Accountants (IFAC), 2018. Handbook of the International Code of Ethics for Professional Accountants. New York: IFAC. Available from: <ifac.org/system/files/publications/files/IESBA-Handbook-Codeof-Ethics-2018.pdf>. [11 July 2019].

Jaworska, E., 2016. Rola zawodowych księgowych w przedsiębiorstwach społecznie odpowiedzialnych. Finanse, Rynki Finansowe, Ubezpieczenia, 2/2(80), 123-131.

Jirásková, S., 2012. Pozice profese účetních na trhu práce v ČR. In Randáková, M. (Ed.). Sborník pedagogické konference Nové požadavky na účetní výkazy v České republice. Praha: Oeconomica, 56-61.

Medical Laboratory Scientists' Association (MLSA), 2017. Národní soustava povolání. Available from: <nsp.cz/hledat>. [11 July 2019]. 
Mužík, J., 1998. Profesní vzdělávání dospělých. Praha: Codex Bohemia. ISBN 97880-7357-738-4.

Povolání, ekonomika, administrativa, personalistika. 2017. Praha: Národní soustava povolání. Available from: <katalog.nsp.cz/vysledekHledani.aspx?q=\%c3\%b a\%c4\%8detn\% $3 \%$ ad\&naKodAlt $=$ True \&char=False \& cin=False \&prikladPr $=$ False $\&$ kzam $=$ False $\&$ isco=False \&cId=81eaee9d-81f8-417a-8de4-61584289b2c9>. $\quad[11$ July 2019].

Riddell, W. C., Song, X., 2011. The Impact of Education on Unemployment Incidence and Re-employment Success: Evidence from the U.S. Labour Market. Labour Economics. 18(4). 453-63.

Š́́pková, K., 2013. Accountants can effectively stabilize business. CFO World. Available from: <https://cfoworld.cz/financni-sluzby/katerina-sipkova-acca-ucetnimohou-ucinne-stabilizovat-byznys-2620>. [11 July 2019].

Suddaby, R., Gendron, Y., Lam, H., 2009. The organizational context of professionalism in accounting. Accounting, Organizations and Society, 34(3-4), 409-427.

Tan, L. M., Laswad, F., 2015. Academic Performance in Introductory Accounting: Do Learning Styles Matter? Accounting Education. 24(5). 383-402.

Tokarčíková, E., Kucharčíková A., Durišová, M., 2015. Education of Students of the Study Program Informatics in the Field of Corporate Social Responsibility, Periodica Polytechnica Social and Management Sciences, 23(2), 106-112.

Watty, K., 2005. Quality in accounting education: what say the academics? Quality Assurance in Education. 13(2). 120-131. ISSN 0968-4883. 
Šeligová, M. - Koštuř́íková, I.: Knowledge of Basic Accounting Issues of SBA Students and their View on the Qualification Level of Professional Accountants. 